\title{
10
}

\section{The genesis of the Social Democratic Liberal Party: A struggle against the odds}

\author{
Pio Tabaiwalu
}

\section{Introduction}

Fiji's political landscape has been shaped along a fractured fault line between the country's two main communities: indigenous Fijians and Indo-Fijians. This legacy of Fiji's colonial past has dogged the country since independence in 1970. The Indo-Fijians are descendants of Indians brought to the colony as indentured labourers by Britain, the then colonial power, to develop a plantation economy. Indo-Fijians came to dominate the economy, arousing resentment from indigenous Fijians. There was increasing fear amongst indigenous Fijians, many of whom lived in semi-subsistence communities, that the Indo-Fijians would ultimately acquire political dominance as well.

This difficult relationship has been the cause of much political upheaval, beginning with the military coup d'état of 14 May 1987 that resulted in the overthrow of the elected government of Prime Minister Timoci Bavadra, the deposition of Elizabeth II as Queen of Fiji, and the declaration of a republic, ending the monarch's reign in Fiji. This was 
followed by a second coup on 28 September 1987. Both military actions were led by Lieutenant Colonel Sitiveni Rabuka, then third in command of the Royal Fiji Military Forces.

The Fiji coup of 2000 was a complicated affair involving a civilian, George Speight, backed by hard line indigenous Fijian nationalists against the elected government of Prime Minister Mahendra Chaudhry on 19 May 2000.

The latest coup was carried out by military commander Commodore Frank Bainimarama, who seized power on 5 December 2006 from elected Prime Minister Laisenia Qarase.

\section{Overview of the conflict}

The 2006 military coup had its origins in the coup of 2000 led by civilian George Speight. The 2000 coup was aimed at the multiethnic government led by Mahendra Chaudhry. After Bainimarama declared martial law and resolved the crisis by force, an interim government was sworn in, headed Laisenia Qarase. Laisenia Qarase and his colleagues in the interim government went on to form the Soqosoqo Duavata ni Lewenivanua (SDL) party and won the elections in 2001 and 2006. Commodore Bainimarama had often said that forming a political party was not part of his 'understanding' with members of the Interim Civilian Government when they were installed. Many commentators have cited this as the beginning of the falling out between Qarase's SDL party and Bainimarama. The SDL had also introduced parliamentary bills that provoked the displeasure of the military.

Three were three bills that were especially contentious to the military and opponents of the SDL government: the Reconciliation Tolerance and Unity Bill (RTU), the Qoliqoli Bill and the Land Tribunal Bill. Perhaps the most significant of these was the RTU bill, which would grant an amnesty to some of those involved in or being investigated for involvement in the coup of 2000.

Relations between the Qarase Government and the Republic of Fiji Military Forces (RFMF) deteriorated from then on. Qarase and his ministers made several attempts to remove the Commander from office: by offering him a diplomatic posting in 2001 and later by resisting the renewal of his contract, and finally by advising the president to remove him. None of these attempts succeeded. 
Political commentators have pointed out that the 2006 military coup was the culmination of the personal ambition of Bainimarama for political leadership. Coupled with this was his attempt to suppress allegations of the misuse of military regimental funds, and his role in the deaths of Counter Revolutionary Warfare Unit (CRW) soldiers who were involved in a mutiny against him in November 2000. Fiji's former police chief, Andrew Hughes, had also launched an investigation into Commodore Bainimarama for alleged sedition after he threatened to overthrow the elected government of Qarase. All these precipitated Commodore Bainimarama's actions against Qarase and his government.

The 2006 general elections once again illustrated historical voting patterns along ethnic lines, with over 80 per cent of the popular vote and all 23 seats reserved for indigenous Fijians going to the SDL, and a similar percentage and all 19 seats reserved for Indo-Fijians going to the Fiji Labour Party (FLP). Overall, the SDL won 36 seats, the FLP won 31 seats and the remaining seats were shared by the United People's Party and independent candidates. The SDL victory must have intensified Bainimarama's resolve to carry out the military coup.

Commodore Bainimarama carried out his coup on 5 December 2006 after months of public vilification of Prime Minister Qarase and of the SDL government.

Bainimarama had supposedly invoked special powers under the Constitution and was using them to dismiss Qarase. On 4 January 2007, executive authority was returned to the President Ratu Josefa Iloilo and Dr Senilagakali resigned as interim prime minister. Ratu Josefa declared his support for the military takeover although he had earlier condemned it as illegal. He then appointed Bainimarama as interim prime minister and also announced the formation of an interim government to lead the country to fresh elections.

\section{The genesis of the Social Democratic Liberal Party}

Under the Political Parties (Registration, Conduct, Funding and Disclosures) Decree 4 2013, the previously registered political parties had 28 days to re-register. Each political party had to collect 5,000 signatures with allocations from Fiji's Central, Western, Northern and 
Eastern administrative divisions. Previously a party only required 180 members to become registered. The membership threshold was a major challenge to the SDL Party.

The more sinister provision of the decree was a requirement that all political parties be named in English rather than Fijian. The SDL Party was keenly aware that the regime wanted to eradicate the party, evidenced by Bainimarama's strong disapproval of SDL policies and a personal falling out with the ousted prime minister, Laisenia Qarase. The provision of the decree to change the name of all parties into English was seen by the party as a direct means to deregister the SDL.

The party hierarchy had initially made a decision to contest the elections as a practical means of moving the country to democratic rule. Rather than changing its name, the SDL Party wound itself up and reformed as the Social Democratic Liberal Party (SODELPA) in order to retain the SDL acronym. However, a subsequent amendment to the Political Parties Decree banned the use of the acronyms of deregistered parties. It was evident that the regime did not want the SDL to exist even as an acronym. However, the decree allowed the use of abbreviations; the party resorted to the abbreviation SODELPA to register as the Social Democratic Liberal Party. The party applied for registration on 26 February 2013, and was registered on 3 May 2013. But the regime had achieved its aim to deregister the SDL Party.

The party was led by Ro Teimumu Kepa as its president and drew up a new constitution. Its stated vision was based on the following:

- commitment to the promotion of peace, stability and economic prosperity and to pursue a policy of dialogue and negotiation at all times to achieve peaceful solutions to Fiji's challenges;

- totally rejecting the notion that such solutions can be reached through acts of violence, force, intimidation and illegality;

- that Fiji's progress must be founded on the rule of law, parliamentary democracy, equity, and social justice for all our people; and

- that the strength of the nation comes from the strength of its component communities and individuals (SODELPA 2013a, p. 2). 
There was a strong commitment from party officials to state categorically in its Constitution the principles of good governance and transparency and to assure all communities that the party embraced and respected the basic rights and freedoms of other communities. It has the following in its aims and objectives:

- to establish a peaceful, caring and prosperous nation;

- to unite the citizens of Fiji and to represent them and their interests fully and with integrity;

- to uphold Christian values and principles and to respect the beliefs and values of other religious faiths;

- to protect, enhance and promote the economic, social and human development of all communities and to secure their future in the Fiji Islands;

- to associate with and/or collaborate with other political parties in order to create an association/alliance for national unity and to promote nation-building;

- to provide the nation with good, honest, dedicated, transparent and competent government and to serve it with devotion;

- to provide policies that prevent all corrupt practices and behaviour; and

- to facilitate and foster positive economic and social development, sustained economic growth and development of all our communities (SODELPA 2013a, p. 2).

From its inception, SODELPA had striven to be attractive to other communities than the Taukei only, knowing that the future of any major political party depended on its cross-ethnic national appeal. This proved to be very difficult, as many perceived SODELPA as just a reincarnation of the SDL and its ethno-nationalist policies. This also became a rallying point for Bainimarama, who frequently referred to party officials as 'old politicians with the same old ideas'.

An important objective of the SODELPA Constitution was the protection and enhancement of the rights of indigenous Fijians, as contained in the United Nation Declaration of the Rights of Indigenous Peoples (UNDRIP) and the International Labour Organization Convention No. 169 on Indigenous and Tribal Peoples. This generated strident views within the party as a consequence of provisions in the 2013 Constitution and specific decrees that were perceived as deliberate 
attempts by the regime to weaken the rights of indigenous Fijians, especially their group rights to their ancestral land. This was best illustrated in the party manifesto as follows:

To the indigenous Fijians land is not just an economic commodity. It is part of culture, kinship and group identity. That is why the Fijians cling so fiercely to their land ownership. The Bainimarama-Khaiyum constitution does not reflect this indigenous attachment to their land.

Their claim that Fijian land has greater protection than before is a lie. Its protection has been weakened. In fact there was no reference at all to native land in the first draft of their constitution. It was left out completely. This caused great fear and uncertainty among landowners. It was only when supporters of SODELPA began to speak out that Bainimarama-Khaiyum decided to include specific reference to native land in their constitution. Without the SODELPA protests they would likely have enacted their supreme law with no special reference to native land. (SODELPA 2013b, p. 89)

The draft constitution by the Yash Ghai Commission that was scrapped by the regime also included a list of protected laws: iTaukei Lands Act (Cap 133), iTaukei Land Trust Act (Cap 134), Rotuma Lands Act (Cap 138), Banaban Lands Act (Cap 124) and Agricultural Landlord and Tenant Act (Cap 270). All these safeguards were not in the constitution drafted by the Bainimarama regime. Instead, in the 2013 Constitution indigenous Fijian land ownership was simply placed alongside a list of provisions in the Bill of Rights. However, section 6 of the Bill of Rights permits rights to be limited and therefore changed. All these rights listed can be subjected to limitations. These developments were of grave concern to traditional stalwarts of the party, who feared a gradual deterioration of the entrenched rights of indigenous Fijians.

Furthermore, since the coup of 2006 the military regime had systematically dismantled and weakened the native Fijian Administration (Matanitu Taukei) and the laws that govern it, which has caused further disaffection among indigenous Fijians. This is clearly reflected in the following decrees:

- the Fijian Affairs Great Council of Chiefs (GCC) Regulation Decree of 2007 to suspend the GCC;

- the GCC Amendment Decree of 2008 to terminate GCC nominees to the Fijian Affairs Board, to be replaced by government appointees; 
- the Fijian Affairs (Provincial Councils) amendment regulation of 2008 to terminate attendance at Provincial Councils of educated urban indigenous Fijians;

- the Fijian Trust Fund (Amendment) (No. 2) Decree 2009 to remove authority of the chiefs from appointing members to the Fijian Trust Fund Board and substituting it with government appointees;

- the Native Land Trust Act (Amendment) (No. 31) Decree 2009 to amend Section 3 of that Act to remove the appointing authority of the chiefs to the Native Land Trust Board and its replacement by the government appointees;

- the Native Land Trust (Amendment) Regulation of 2010 that terminated the share of royalty income for the chiefs;

- the Mahogany Industry Development Decree (No. 16) of 2010 that terminated iTaukei Land Trust Board's (TLTB) power and authority over mahogany leases on native land and the power to negotiate financial return on mahogany plantations and its replacement by a Mahogany Industry Council headed by Prime Minister Voreqe Bainimarama;

- the Regulation of Surfing Areas Decree (No. 35) of 2010 that terminated control of surfing areas by iTaukei and their trustee TLTB, vesting all rights in the government;

- the Native Land Trust Act (Amendment) (No. 31) Decree 2010 to terminate reference to indigenous 'Fijians' to be replaced by the label 'iTaukei' and application of the label 'Fijian' to all citizens of Fiji without consideration of the views, and consent of, the indigenous Fijian;

- the Native Land Trust (Amendment) (No. 32) Decree 2010 to amend Section 3 of that Act to vest control of that institution in the minister, who replaces the president as representative of the chiefs and customary landowners; and removing chiefly representation to the board, replacing it with the government and prime minister as sole appointing authority;

- the iTaukei Land Trust (Amendment) (No. 20) Decree 2012 to amend Section 19 of that Act to remove the GCC as authority to determine customary ownership and its replacement with government authority;

- the iTaukei Affairs (Amendment) (No. 22) Decree 2012 to amend Part 2 of that Act to remove and terminate the existence of the GCC; 
- the iTaukei Trust Fund (Amendment) Decree (No. 23) of 2012 that terminated the GCC administrative power of the Fijian Trust Fund;

- the Land Use Decree (No. 36) of 2010 that gave to the prime minister unfettered power to designate native land to a land bank, to be administered by the Land Use Unit and Director of Lands;

- the Native Land Trust (Amendment) Decree (No. 20) of 2010 that terminated the GCC's authority over extinct mataqali land;

- the Native Land Trust (Amendment) Decree (No. 20) of 2012 that terminated the power of the GCC to determine customary ownership of extinct mataqali land;

- the iTaukei Trust Fund (Amendment) (No. 23) Decree 2012 to remove any reference to the GCC and the need to provide for its financial autonomy;

- the Unit Title (Amendment) Decree (No. 38) of 2013 that removed the restriction of that Act on native land.

The 2013 Constitution had further weakened indigenous Fijian group rights; there is no reference to the Deed of Cession and its historical significance, as in the 1997 Constitution. The Deed of Cession was for many indigenous Fijians the basis on which they could rightly claim their inheritance as first inhabitants, including their inalienable rights to their traditional lands and resources.

Moreover, the 1970 and 1997 Constitution had special entrenched provisions, providing extremely strong safeguards for indigenous Fijian, Rotuman and Banaban landownership. These constitutional provisions laid down very detailed and entrenched procedures for altering the following: the Fijian Affairs Act; Fijian Development Act; Native Lands Act; Native Lands Trust Act; Rotuma Act; Rotuma Lands Act; Banaban Lands Act; and the Banaban Settlement Act. These entrenched provisions are no longer in the 2013 Constitution.

There is also no provision in the 2013 Constitution on customary law and customary rights, which were provided for in the 1997 Constitution as group rights. This would have allowed the application of such laws in the proper maintenance and observance of customary practices. 
The 1997 Constitution stated as follows:

Customary laws and customary rights

186. (1) The Parliament must make provision for the application of customary laws and for dispute resolution in accordance with traditional Fijian processes.

(2) In doing so, the Parliament must have regard to the customs, traditions, usages, values and aspirations of the Fijian and Rotuman people.

(3) The Parliament must make provision granting to the owners of land or of registered customary fishing rights an equitable share of royalties or other moneys paid to the State in respect of the grant by the State of rights to extract minerals from the land or the seabed

(Fiji Constitution 1997, Section 186)

Coupled with the above, the military regimes took control of all companies established under Fiji's semi-autonomous native administration (Matanitu Taukei), including Fijian Holdings Limited and the Native Land Trust Board, the government agency that administers native land (SODELPA 2013b, p. 38).

The above actions by the regime were perceived by SODELPA as a deliberate attempt by the regime to regress indigenous rights. This suppression of the communal group rights of indigenous Fijians, for the creation of a progressive nation-state, is clearly espoused by the military regime's Attorney General Aiyaz Sayed-Khaiyum in his unpublished thesis. In his conclusion Khaiyum states as follows:

Therefore cultural autonomy must have a sunset clause. Its prolonged continuation will place a stranglehold on the very members it seeks to protect and it will concomitantly disallow the critical cultural space in which a just, vibrant and coherent nation-state can flourish while embracing diversity. (Sayed-Khaiyum 2002, p. 69)

But such impositions will not create a stable and lasting solution to Fiji's long-term stability as a multicultural nation. As Jon Fraenkel states, 'It is inconceivable that an assault on the institutions of indigenous Fijian post-colonial rule will yield a viable future for that country' (Fraenkel 2014, p. 1). 
This will be a major challenge in the years ahead as SODELPA tries to reconcile its traditional base voters, who perceive the threat to the deterioration of their rights as indigenous people on the one hand, and the need to address the social and economic needs of a new, more urbanised voter on the other.

In addition, the voting age was reduced to 18 years, which has its own political dynamic. Many young voters will have not voted before and many are divorced from the traditional sentiments about indigenous concerns such as the GCC or land rights. For them, bread and butter issues, access to education and job opportunities are critical factors. As Jon Fraenkel states:

The main opposition party, SODELPA, chose to campaign - as Laisenia Qarase did in 2001 and 2006-by appealing mainly to the indigenous Fijian community on issues such as hostility to the dissolution of the Great Council of Chiefs and threats to indigenous Fijian land ownership. These issues struck a chord amongst older ethnic Fijian voters, but they carried little weight among the younger generation. With the voting age reduced to 18, these voters held sway in 2014. (Fraenkel 2014, p. 1)

In examining the new voting system and the demographic distribution, SODELPA party officials were always aware that they could not win the elections alone. They needed the other opposition parties to win some of the seats, with the intention of going into a coalition to form a government. Contrary to Fraenkel's observation, SODELPA also had economic, social, governance and bread and butter issues in its manifesto. The pliant media had become a propaganda tool for the regime and SODELPA could not get its other progressive messages across.

\section{The restrictive political environment}

Although Voreqe Bainimarama stepped down eventually from leadership of the army, before the general elections it was evident that Fiji was still governed by a military-backed dictatorship. The promulgation of restrictive decrees placed severe limitations on the ability of political parties to launch their political campaigns. 
For instance, the Political Parties Decree stated that a person who had been convicted and imprisoned for an offence for a period of six months or more in the last five years cannot be a party official. This effectively ruled out Qarase, who had served a year-long prison sentence after he was convicted for offences committed before he was prime minister. The same provision later ruled out Mahendra Chaudhry, the FLP leader. The decree also banned trade union officials from being political party officials; many commentators believed this provision targeted union officials like Felix Anthony (National Secretary of the Fiji Trades Union Congress) and Attar Singh (General Secretary of the Communications, Mining and General Workers Union), who had shown keen interest in contesting the elections. An amendment to the decree also nullified the candidacy of Anare Jale, a strong and popular candidate for SODELPA, and unfairly disqualified some opposition party candidates because they had been overseas for more than 18 months prior to the writ of elections. The party perceived all these restrictive sections of the decree as an attempt by the regime to weaken prominent opposition figures at the polls.

Increasingly, within the regime decisions were made by a few, there was no consultation with political parties and information was published through the pliable media. Repressive and undemocratic decrees were promulgated, such as the State Services (Amendment) Decree 2000; Public Order Amendment Decree 2012; the Media Industry Development Decree 2010; the Political Parties (Registration, Conduct, Funding and Disclosures) Decree 4 2013; the anti-worker and anti-union Essential National Industry (Employment) Decree 2011; Regulation of Pension and Retirement Allowances Decree 2009; and the Compulsory Registration of Customers for Telephone Services Decree 2010. These decrees placed severe limitations on activities that would provide for more transparent democratic processes to ensure free and fair elections.

\section{The muzzling of the media}

The media industry had been under severe censorship since the military coup of December 2006. The people saw for themselves the pervasive damaging influence of the Media Decree on the quality and content of what was reported. Many journalists spoke 
of the self-censorship in the newsroom. The net effect is that what eventually came out as news was heavily truncated and edited by regime lackeys. There were many complaints lodged with the Media Industry Development Authority (MIDA) by concerned citizens and SODELPA party officials, but nothing eventuated. There was also growing unease that MIDA may have been unduly influenced by the regime due to its lack of response to the pro-regime propaganda and the suppression of opposition views.

Section 22 of the Media Industry Development Decree states that content must not include material, which is (a) against the public interest or order; (b) against the national interest; or (c) creates communal discord. This provision effectively regulated how the media generated its news and in many instances was selectively interpreted by the regime.

The heavy penalties for a breach of the decree also placed undue pressure on the media to exercise self-censorship. Upon conviction for any breaches of the media code, a media organisation could be fined FJD\$100,000; a publisher/editor FJD\$25,000 and/or two years imprisonment; and a journalist or media FJD $\$ 1,000$ and/or two years imprisonment.

A free and fair media without the restrictive and selective interpretations of the Media and MIDA Decrees was essential to balanced reporting in terms of the opposition parties getting their views and opinions to the general public.

This lack of media coverage proved to be a crucial factor in the overall performance of the opposition parties at the polls, including SODELPA. They were simply shut out of the media, and with less visibility and coverage it was always going to be an uphill battle for them.

\section{A system of elections to suit the FijiFirst Party}

It became quite clear to SODELPA that the system of elections that was imposed on the country by the regime would favour Bainimarama's FijiFirst. The system of voting is prescribed in the 2013 Fiji Constitution as follows: 
53. (1) The election of members of Parliament is by a multi-member open list system of proportional representation, under which each voter has one vote, with each vote being of equal value, in a single national electoral roll comprising all the registered voters and

(3) A political party or an independent candidate shall not qualify for any seat in Parliament unless the political party or the independent candidate receives at least $5 \%$ of the total number of votes cast. (Fiji Government 2013)

SODELPA was supportive of a multiple constituency system that would allow representations in specific constituencies and allow voters to cast their votes along party lines. But the regime had chosen a single national electoral roll - a system that would ultimately benefit it.

Furthermore, the rejection by Bainimarama of the Yash Ghai draft should be seen in the context of the overall election strategy of FijiFirst and its performance at the polls. As explained by Wadan Narsey:

First, the Ghai draft electoral system had four constituencies (the divisions), apparently a trivial difference, but it would have limited Bainimarama to appear on the ballot paper for only one constituency and hence strictly limited his personal vote appeal. All other FF candidates in the other three constituencies would have had to struggle for votes against other competitors, instead of riding on Bainimarama's coat-tails.

Second, the Bainimarama government would have had to resign six months before the election. This would have prevented Bainimarama and his ministers from using taxpayers' funds and donor-funded projects, right up to polling day, in blatant and very successful vote buying.

Third, Bainimarama would not have had the complete control over the media through their restrictive media decrees (including the Media Industry Development Authority - MIDA) to obtain maximum political mileage for themselves, while criticising and ruthlessly suppressing opposition parties.

Fourth, to obtain immunity, Bainimarama and his coup collaborators would have had to express remorse for specific actions for which they wanted immunity, with clearly negative consequence for their image with voters. (Narsey 2004, p. 1) 
Apparently, the Yash Ghai draft constitution was discarded and a new one manufactured to put in place the most conducive electoral system to win the elections for Bainimarama's intended party.

The electoral decree came out in March 2014, although the regime had earlier promised that it would be ready by December 2013. The lateness of the electoral decree, which took an inordinately long time to draft, was another ploy by the regime to restrict the time for other political parties to prepare for elections.

The decree also had provisions that were clearly against free and fair elections. SODELPA had conveyed the following issues to the Electoral Commission:

- party symbols to be part of the ballot paper and candidates be grouped together under their respective party symbol instead of just having the numbers of the candidates;

- adequate training to be provided for party officials and agents;

- examination of the role of media and their self-induced censorship as a consequence of the restrictive provisions of the Media Industry Development Decree;

- allow more public political rallies, the number of which was limited by the Public Order Amendment Decree;

- allow a more diverse group of observers for the elections, especially local NGOs who were prevented from observing the elections by the Electoral Decree 2014;

- the Commission to take a more proactive role in the build-up to the elections to engender public confidence in the neutrality of the process;

- the excessive penalty for any person who contravened the Electoral Decree, who would be liable upon conviction to a fine not exceeding FJD $\$ 10,000$ or to a term of imprisonment not exceeding 5 years, or to both; and

- to amend the provisions in the Electoral Decree 2014 that allowed the Supervisor of Elections and his staff indemnity from court actions as a result of decisions they undertake.

The Electoral Decree stated that the ballot paper was to have only numbers, with no names, no photos and no party symbols. SODELPA, with other political parties, made many representations to the 
Commission to seek changes to the ballot paper, particularly the need to have party symbols to assist voters. This eventually culminated in the production of a handbook that had the names, photos and numbers of candidates, which could be consulted by voters before placing a tick on the number of the candidate of their choice on the ballot paper. But this made little difference, as the ballot paper only had the number and was clearly to the advantage of FijiFirst, which was promoting just one number.

It is abundantly clear now that the entire electoral system and electoral decree was cunningly designed to suit the Bainimarama campaign for voters to remember only one number (279) while ignoring all other candidates. (Narsey 2014)

It was quite apparent that the FijiFirst strategy was to ask voters to vote for just the one number representing Bainimarama, and this was heavily advertised through the media and campaign material. The large number of votes for Bainimarama hauled in many of his FijiFirst colleagues with fewer votes than those for SODELPA candidates who did not get into Parliament. Many will question whether this was a 'democratic' representation of voters and the validity of the mantra of 'one man, one vote, one value'.

The electoral system had also imposed a 5 per cent threshold rule that disadvantaged small parties and independents. The total votes lost due to the very high threshold resulted in FijiFirst getting 3 extra seats. This was another gain to the regime's party that was foreseen and written into the relevant decree.

\section{The elections authorities}

To ensure control over the process of elections, the Bainimarama regime chose as the Minister of Elections its own Attorney General (Aiyaz Sayed-Khaiyum), who was also the secretary-general of FijiFirst Party. This was a blatant exposition of political control to ensure an election that was in all ways and means to their advantage.

In addition, the Supervisor of Elections, Electoral Commission members, and the MIDA chairman were all seen by the party as pawns in the build-up to elections, as most of them were well known regime sympathisers. 
The Electoral Decree also deemed:

it shall be unlawful for any person, entity or organization that receives any funding or assistance from a foreign government, intergovernmental or non-governmental organization or multilateral agency to engage in, participate in or conduct any campaign (including organizing debates, public forum, meetings, interviews, panel discussions, or publishing any material) that is related to the election or any election issue or matter. (Fiji Government 2014)

This provision barred local NGOs from educational activities related to the elections and effectively restricted the boundaries for free and fair elections. The Electoral Commission was going to conduct all the training and from the party's perspective that was inadequately done.

There was also the decision by the Minister for Elections and secretary of the FijiFirst Party that while international observers of his choice would be allowed to monitor the elections, no local observers would be allowed, although it was clear that local observers would have had a better understanding of local issues and possible discrepancies in the process.

It was abundantly clear that after numerous efforts by SODELPA for a level playing field, the election authorities were doing very little to try to make the elections genuinely 'free and fair', despite the restrictive Electoral Decree and the compromised media environment.

\section{SODELPA at the polls}

The SODELPA party executives were well aware that it was going to be a hard-fought battle at the polls. The base voters of the party would have to be the iTaukei, with a total of 297,818 votes comprising nearly 60 per cent of the total votes of 496,364 . The party had to win 52 per cent of the total national votes to get the 26 seats required to govern on its own. This meant that if it wanted to target just the iTaukei then it had to win over 80 per cent of their votes. This was a near impossible task.

The strategy was to go after the iTaukei votes with the hope that the other two major political parties, the National Federation Party (NFP) and the Fiji Labour Party (FLP), would win enough seats 
to form a coalition government. This was first articulated by party leader Ro Teimumu Kepa in his maiden speech as party leader of SODELPA, where he invited other opposition parties to be part of a grand coalition. This was the only feasible strategy in the face of overwhelming odds, given that FijiFirst had been in power for nearly eight years and controlled the media and the rules for elections.

SODELPA won 139,857 votes, which translated into 15 seats in Parliament; and with NFP winning three seats and the FLP winning none the party fell short of the targeted 26 seats.

FijiFirst also had the advantage over other parties in terms of resources and the fact that they were in power in the form of the post-coup regime and had control over the political and coercive means to restrict the media and freedom of association and was in control of development projects which it marketed effectively to voters.

Eight years of authoritarian rule and unrivalled hegemony entrenched their visibility, familiarity and relevance in the consciousness of voters. (Ratuva 2014)

Although SODELPA could not form government as a coalition as intended, the result was positively considered as a first step towards parliamentary democracy.

\section{Conclusion}

The triumph of coup perpetrator Bainimarama and his FijiFirst Party illustrates how a military commander treasonably deposed a lawfully elected government and yet managed to become legitimised as an elected prime minister. All it took was a systematic approach to controlling the election boundaries and the decrees that were, for all intents and purposes, engineered to give him victory at the polls.

Bainimarama has frequently stated that the coup's objective was to bring about a more united Fiji, with a new vision of statehood. But as Jon Fraenkel observes:

Surveying the international experience of coups aimed at bridging ethnic divisions, it is striking how few cases give credence to that objective. West African military coups after independence were frequently depicted as efforts to counter tribalism or tackle civilian 
corruption, but almost invariably proved to be instruments for the triumph of militarised ethnocracy. Coups aimed at countering ethnic polarisation tend to morph quickly into vehicles for the ascendancy of one or the other group. (Fraenkel 2009)

Another chapter could be written on the continuation of military dictatorship under the guise of parliamentary democracy; while the country boasts a democratically elected government, Frank Bainimarama and Aiyaz Sayed-Khaiyum's modus operandi for the past eight years has not changed. Some claimed that the country merely transitioned to a parliamentary dictatorship.

For the SODELPA party, winning 15 seats was a consolation of sorts after eight long years of a military regime. The party fielded 48 candidates, with the strategy of getting as many votes as possible and to cover a wider geographical area. Many observers stated that SODELPA should have done better, but with the cards stacked high against it the party was always realistic that without the support of other parties, it would be extremely difficult to be in government on its own.

\section{References}

Fiji Constitution 1997, Constitution of the Republic of the Fiji Islands Amendment Act 1997, Fiji Government Printer, Suva, Fiji.

Fiji Government 2013, Constitution of the Republic of the Fiji Islands 2013, Fiji Government Printer, Suva, Fiji (September 2013).

Fiji Government 2014, Fiji Electoral Decree, Fiji Government, Suva.

Fraenkel, Jon 2009, 'The Fiji coup and the politics of ethnicity'. Available from insidestory.org.au/the-fiji-coup-and-the-politics-ofethnicity.

Fraenkel, Jon 2014, 'Observations on Fiji's 2014 election'. Available from pidp.eastwestcenter.org/pireport/2014/September/09-24-an.htm.

Narsey, Wadan 2014, 'Fiji elections: Another victory for treason, lies, money and the culture of silence', Pacific.Scoop. Available from pacific.scoop.co.nz/2014/09/fiji-elections-another-victory-fortreason-lies-and-the-culture-of-silence/. 
Ratuva, Steven 2014, 'A symbol of hope-reflections on the Fiji election'. Available from pacific.scoop.co.nz/category/opinions/.

Sayed-Khaiyum, A 2002, 'Cultural autonomy-Its implication on the nation state: The Fijian experience', unpublished Master in Law thesis, University of Hong Kong.

SODELPA 2013a, 'Party Constitution', Social Democratic Liberal Party Secretariat, Suva, Fiji (June 2013).

SODELPA 2013b, 'Party Manifesto', Social Democratic Liberal Party Secretariat, Suva, Fiji (August 2013). 
This text is taken from The People Have Spoken: The 2014 Elections in Fiji, edited by Steven Ratuva and Stephanie Lawson, published 2016 by ANU Press, The Australian National University, Canberra, Australia. 